\title{
Ecological sustainability methodology for logistic chains of milk supply
}

\author{
Sergei Korolev $^{1, *}$, Julia Ertman ${ }^{1}$, and Sergei Ertman ${ }^{1}$ \\ ${ }^{1}$ Tyumen Industrial University, Tyumen, Russian Federation
}

\begin{abstract}
This article considers the importance of assessing the environmental impact of logistics supply chains in the transition to a circular economy. We propose to use product life cycle analysis as a base assessment, decomposing raw milk supply chains and assessing the environmental im-pact of packages of various process options and supply chain configurations. As a result, we have obtained the checklist for assessing the environmental sustainability of supply chains and developed a three-level scale. An example of applying the developed methodology for evaluating three different enterprises of the Tyumen region is given. Based on the results ob-tained, we can draw conclusions about the possibilities of practical use and the directions of the following studies.
\end{abstract}

\section{Introduction}

In the modern world, the fact of the existence of global environmental problems is no longer in doubt. There is debate about the seriousness of the situation, about how quickly humanity is approaching the "point of no return", and climate change may become irreversible. But the agenda of disputes, as a rule, does not include recognition that anthropogenic impact is the main reason for the depletion of the ozone layer, melting of glaciers due to the greenhouse effect, acid precipitation, the growth of human waste, erosion and soil, degradation, deforestation and much more [1-3].

The circular economy is one of the guidelines designed to reduce environmental impact based on saving and renewing resources, processing secondary raw materials, and switching to the use of renewable energy sources $[4,5]$.

Thus, the requirements of modernization of the economy, its transition to a circular model, are dictated by the need to reduce environmental degradation. The obvious conflict between the need for industrial development in the face of fierce competition and environmental protection in the transition to a circular economy has led to the emergence of theories and practices for companies wishing to take into account environmental requirements without sacrificing profitability. "Green Supply Chain Management" (GSCM) is such an emergent environment that implies sustainable organizational technological innovations through the integration of environmental issues into organizational activities for the supply chain management [6].
The dairy industry is critically important for the economy in Russia. Milk and dairy products are included in the list of products of the Doctrine of National Food Safety and play a paramount role in the diet of the population. Currently, the supply of domestic dairy products in the Russian Federation is less than 85\%, while the threshold value set by the Food Safety Doctrine is $90 \%$. The current state of the dairy industry is low average efficiency, instability and nontransparency of all parts of the supply chain. Despite the fact that agriculture exerts significant environmental pressure, the issues of assessing the environmental impact of dairy production have not been sufficiently studied, there is no methodology for a comprehensive assessment of the environmental sustainability of the supply chains of milk and dairy products $[7,8]$.

Thus, work aimed at improving the environmental sustainability of raw milk supply chains based on the principles of a circular economy is relevant.

\section{Methods}

To focus on environmental performance management in the field of logistics management of milk supply chains, it is necessary to be able to objectively and comprehensively assess the environmental impact of supply chains [9-11]. General requirements for such an assessment were formulated based on an analysis of previous studies. So, an assessment of the environmental impact of supply chains:

- must be applicable to any supply chain, allow the evaluation of goods, services, various solutions and

\footnotetext{
* Corresponding author: everisposs@mail.ru
} 
configurations in terms of environmental impact and be suitable for comparison purposes;

- take into account all stages of the life cycle of a service or product manufactured at the enterprise;

- take into account options for different types of exposure: creating a steam boost effect, depletion of natural resources, water consumption, toxicity to humans and others (fig. 1);

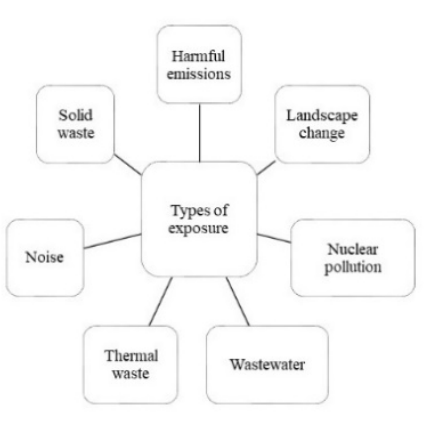

Fig. 1. Types of environmental impact and their consequences

The LCA method meets these requirements. LCA or life cycle analysis is an internationally recognized methodology [12-13] for environmental impact analysis throughout the entire life cycle. This allows not only to evaluate in detail the individual elements of the decomposed process at all stages of the life cycle, but also to conduct a comprehensive assessment using indicators that can bring various types of environmental impact to a "common denominator".

Schematically, the main links and components of the raw milk supply chain are presented in Fig. 2.

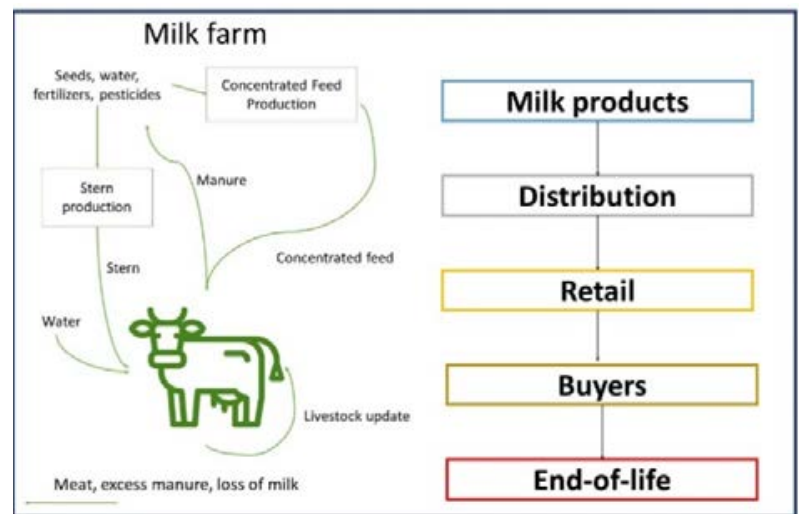

Fig. 2. Key links and components of the milk supply chain.

The analysis allowed typologizing the environmental impact of raw milk production and its supply chains. Three main categories were identified: use of natural resources, waste generation and greenhouse gas emissions [14]. Categories and types of environmental impact are presented in table 1.
- provide information on the environmental impact of each of the components and at all stages of the product life cycle;

- allow you to evaluate decisions made in terms of environmental impact changes;

- allow arguing the reason for the importance of reducing the environmental impact (which is of great importance in the Russian environment of insufficient environmental awareness).

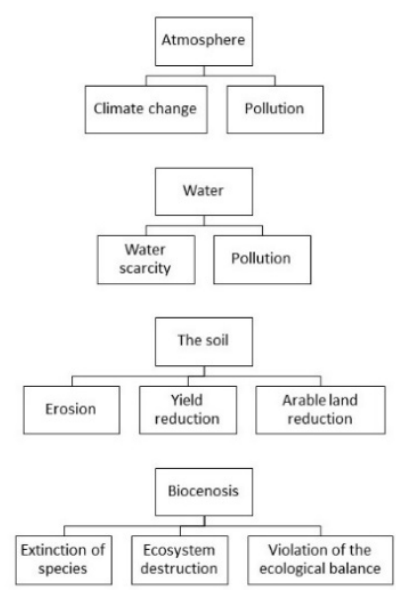

Table 1. Environmental Impact Categories.

\begin{tabular}{|c|c|}
\hline Impact category Impact type & Type of exposure \\
\hline Depletion of natural resources & $\begin{array}{c}\text { Use of resources (raw } \\
\text { materials, water, energy, } \\
\text { materials, etc.) }\end{array}$ \\
\hline Waste generation & $\begin{array}{c}\text { Wastewater formation, milk } \\
\text { loss }\end{array}$ \\
\hline Greenhouse gas emissions & $\begin{array}{c}\text { Carbon dioxide, sulfur oxide, } \\
\text { methane emissions during } \\
\text { transportation and at all stages } \\
\text { of milk production, Freon } \\
\text { emissions }\end{array}$ \\
\hline
\end{tabular}

At a dairy farm, the main components of environmental impact are the consumption of electricity and water. However, the use of electricity and water occurs in all parts of the supply chain of dairy products from milking to delivery of finished products to the consumer's table [15-16].

Another component of a significant contribution to the overall environmental impact is the numerous losses of milk at all stages of dairy production, which also leads to a decrease in profitability and competitiveness. The use of milk is an expensive and environmentally expensive process, and any actions aimed at reducing losses have an unconditional positive effect.

Greenhouse gas emissions, in turn, occur precisely on the farm and during transportation. According to the Food and Agriculture Organization of the United Nations, cattle account for $20 \%$ of the global production of greenhouse gases and methane.

Structural decomposition of raw milk supply chains allowed us to single out individual work packages (operations) related to environmental damage, as well as to approximately estimate the damage caused in the three established categories, taking into account the different 
ways of performing a specific operation. (based on $600 \quad$ heads of cattle) (table 2).

Table 2. Environmental impact assessment of individual raw milk supply chains, taking into account various options for operations.

\begin{tabular}{|c|c|c|c|c|c|c|}
\hline \multirow[b]{2}{*}{ Process name } & \multirow[b]{2}{*}{$\begin{array}{c}\text { Method } \\
\text { of } \\
\text { implementation }\end{array}$} & \multicolumn{2}{|c|}{ Depletion of natural resources } & \multicolumn{2}{|c|}{ Waste generation } & \multirow[b]{2}{*}{$\begin{array}{l}\text { Greenhouse } \\
\text { gas emissions }\end{array}$} \\
\hline & & Water costs, \% & $\begin{array}{c}\text { Expenses } \\
\text { electricity, } \\
\text { kWh } \\
\end{array}$ & $\begin{array}{c}\text { Milk } \\
\text { loss, } \\
\%\end{array}$ & $\begin{array}{c}\text { Wastewater } \\
\text { formation, } \% \text { of } \\
\text { water volume }\end{array}$ & \\
\hline \multirow{4}{*}{ Milking } & Hand milking & 25 & - & 3 & 25 & \\
\hline & Milking robot & 15 & $40-72$ & 1.5 & 15 & \\
\hline & Linear milk line & 16 & $5-20$ & 2 & 16 & \\
\hline & Milking parlor & 17 & $5-30$ & 1.7 & 17 & \\
\hline \multirow{3}{*}{ Milk cooling } & Tank cooler & 10 & $30-35$ & 2 & 10 & \\
\hline & Outdoor bath & 11 & 36 & 2 & 11 & \\
\hline & Flow cooler & 12 & $15-30$ & 2.5 & 12 & \\
\hline \multirow{3}{*}{$\begin{array}{l}\text { Transportation to } \\
\text { the factory }\end{array}$} & & $\begin{array}{c}\text { Water } \\
\text { consumption per } \\
6 \mathrm{~m} 3 \text {, liters } \\
\end{array}$ & $\begin{array}{c}\text { Fuel } \\
\text { consumption, l } \\
/ 100 \mathrm{~km} \\
\end{array}$ & $\begin{array}{c}\text { Milk } \\
\text { loss, } \\
\% \\
\end{array}$ & $\begin{array}{l}\text { Soot emissions, } \\
\text { gram / km }\end{array}$ & $\begin{array}{l}\text { Greenhouse } \\
\text { gases CO2, } \\
\text { gram / km }\end{array}$ \\
\hline & Petrol engine & 480 & $14-35$ & 2.5 & & $160-240$ \\
\hline & Diesel engine & 480 & $14-35$ & 2.5 & $4-40$ & $120-170$ \\
\hline \multirow{2}{*}{$\begin{array}{l}\text { Transportation } \\
\text { from the factory }\end{array}$} & Petrol engine & 120 & $12-30$ & 1.5 & & $160-240$ \\
\hline & Diesel engine & 120 & $12-30$ & 1.5 & $4-40$ & $120-170$ \\
\hline
\end{tabular}

The developed table can serve as a checklist for assessing the environmental impact of the supply chains of dairy products of various production options, various production volumes and various configurations.

It can be said that Russian producers of the dairy industry for the most part consider environmental protection measures as a problem associated with additional costs and, thus, negatively affecting profitability and competitiveness. At the same time, we are witnessing the processes of transformation of environmental consciousness in the world, which lead to the understanding that environmentally friendly value chains are not a "problem", but a "possibility", a competitive advantage. Sustainable supply chain management implies implementation through hard (for example, cleaner production equipment) and soft management (for example, expanding cooperation with suppliers in the field of eco-design) $[17,18]$.

As a proactive environmental management practice, GSCM can be directly aimed at reducing environmental damage through the implementation of various environmental measures, as well as at preserving environmental efforts by reducing energy and resource consumption, which will not only reduce the environmental impact, but also reduce costs [19-21].

Considering the ecological state of the dairy industry, based on the studies conducted, it is possible to offer not so much an assessment of environmental innovations as a state of affairs, the level of compliance with environmental requirements. Thus, in order to interpret the results obtained, the levels of environmental compliance were developed based on the average values of resource consumption in the Russian Federation (table 3).
Table 3. Environmental Sustainability of supply chain.

\begin{tabular}{|c|c|c|c|}
\hline \multirow{2}{*}{$\begin{array}{l}\text { Environmental sustainability } \\
\text { indicators }\end{array}$} & \multicolumn{3}{|c|}{$\begin{array}{c}\text { Environmental } \\
\text { sustainability levels }\end{array}$} \\
\hline & high & average & low \\
\hline $\begin{array}{l}\text { the cost of water on the total volume } \\
\text { of production, } \%\end{array}$ & $\begin{array}{l}\text { less } \\
\text { than } \\
0.37\end{array}$ & $\begin{array}{l}0.37 \text { to } \\
0.4\end{array}$ & $\begin{array}{c}\text { more } \\
\text { than } \\
0.41\end{array}$ \\
\hline electricity costs, $\mathrm{kw} * \mathrm{~h}$ & $\begin{array}{c}\text { less } \\
\text { than } \\
65\end{array}$ & 65 to 95 & $\begin{array}{c}\text { more } \\
\text { than } \\
95\end{array}$ \\
\hline waste, \% & $\begin{array}{c}\text { less } \\
\text { than } \\
7\end{array}$ & 7 to 7.5 & $\begin{array}{c}\text { more } \\
\text { than } \\
7.5\end{array}$ \\
\hline $\begin{array}{l}\text { Environmental standard used in } \\
\text { vehicle supply chains }\end{array}$ & $\begin{array}{c}\text { euro } \\
5 \\
\text { and } \\
\text { more }\end{array}$ & euro 4 & $\begin{array}{c}\text { euro } \\
3 \\
\text { and } \\
\text { less }\end{array}$ \\
\hline total transportation distance, $\mathrm{km}$ & $\begin{array}{c}\text { less } \\
\text { than } \\
30\end{array}$ & $30-60$ & $\begin{array}{c}\text { more } \\
\text { than } \\
60\end{array}$ \\
\hline
\end{tabular}

\section{Results and Discussion}

To test the developed methodology, we evaluated the environmental impact of raw milk supply chains supplied to retail chains from manufacturers of the Tyumen region: CJSC "Yasen-Agro", OJSC "Sovkhoz "Chervishevsky", PC "Milk". The choice was due to the availability of necessary data on enterprises in open sources, in open reports and publications in the media, as well as the fact that enterprises from the sample are leaders in the production of dairy products in the Tyumen region and are ahead of production in terms of equipment used.

All companies follow a closed cycle, which means that they themselves receive raw materials, process and sell it, and get rid of residues from unsold products.

The source data for the assessment of enterprises are presented in table 4 . 
Table 4. Initial data for assessment.

\begin{tabular}{|c|c|c|c|}
\hline & $\begin{array}{c}\text { CJSC "Yasen- } \\
\text { Agro" }\end{array}$ & $\begin{array}{c}\text { OJSC "Sovkhoz " } \\
\text { Chervishevsky" }\end{array}$ & PC "Milk" \\
\hline Type of milking & Milking parlor & Milking robot & Linear milk line \\
\hline Milk yield, 600 head & 6000 & 7200 & 4800 \\
\hline Milk cooling & Tank cooler & Tank cooler & Tank cooler \\
\hline Distance to the plant, km & 61 & 4 & 8 \\
\hline $\begin{array}{c}\text { The distance from the } \\
\text { factory to the shops, km }\end{array}$ & 70 & 40 & Euro 4 \\
\hline $\begin{array}{c}\text { Environmental standard } \\
\text { used cars }\end{array}$ & Euro 3 & Euro 4 & 80 \\
\hline
\end{tabular}

In the tables 5-7, the initial data are presented for comparison using the developed checklist based on the characteristics of the equipment and recalculation of production costs per liter of finished products (Table 57).

Table 5. Initial data for assessment the CJSC "Yasen-Agro".

\begin{tabular}{|c|c|c|c|c|c|c|c|}
\hline \multirow[b]{2}{*}{ Process name } & \multirow{2}{*}{$\begin{array}{l}\text { Method of } \\
\text { implementat } \\
\text { ion }\end{array}$} & \multicolumn{2}{|c|}{ Depletion of natural resources } & \multicolumn{3}{|c|}{ Waste generation } & \multirow{2}{*}{$\begin{array}{c}\text { Greenhouse } \\
\text { gas } \\
\text { emissions }\end{array}$} \\
\hline & & $\begin{array}{l}\text { Water } \\
\text { costs, } 1\end{array}$ & $\begin{array}{l}\text { The cost of } \\
\text { electricity, kWh }\end{array}$ & $\begin{array}{l}\text { Losses } \\
\text { milk, } \\
\%\end{array}$ & \multicolumn{2}{|c|}{$\begin{array}{c}\text { Wastewater } \\
\text { formation, \% of } \\
\text { volume }\end{array}$} & \\
\hline Milking & $\begin{array}{l}\text { Milking } \\
\text { parlor }\end{array}$ & 1020 & 25 & 1.5 & \multicolumn{2}{|c|}{100} & \\
\hline Milk cooling & Tank cooler & 600 & 25 & 2 & \multicolumn{2}{|c|}{100} & \\
\hline \multirow[t]{2}{*}{$\begin{array}{l}\text { Transportation } \\
\text { to the factory }\end{array}$} & & $\begin{array}{c}\text { The cost of } \\
\text { water per } 6 \\
\text { cubic } \\
\text { meters. m } \\
\text { liters }\end{array}$ & $\begin{array}{c}\text { Fuel } \\
\text { consumption, l / } \\
100 \mathrm{~km}\end{array}$ & $\begin{array}{l}\text { Losses } \\
\text { milk\% }\end{array}$ & \multicolumn{2}{|c|}{$\begin{array}{l}\text { Soot emissions, } \\
\text { gram / km }\end{array}$} & $\begin{array}{l}\mathrm{CO} 2 \\
\text { emissions, } \\
\text { grams }\end{array}$ \\
\hline & Diesel engine & 480 & 9.76 & 2.5 & \multicolumn{2}{|c|}{915} & 8662 \\
\hline $\begin{array}{c}\text { Transportation } \\
\text { from } \\
\text { the factory }\end{array}$ & Diesel engine & 120 & 11.2 & 1.5 & \multicolumn{2}{|c|}{1050} & 9940 \\
\hline \multirow[t]{2}{*}{ Total } & Water costs, 1 & $\begin{array}{c}\text { Electricity, } \\
\text { kWh }\end{array}$ & $\begin{array}{c}\text { Fuel } \\
\text { consumption, l }\end{array}$ & $\begin{array}{l}\text { Loss of } \\
\text { milk, \% }\end{array}$ & $\begin{array}{c}\text { Wastewa } \\
\text { ter, l }\end{array}$ & $\begin{array}{l}\text { Soot, } \\
\text { gram }\end{array}$ & $\begin{array}{c}\text { CO2 } \\
\text { emissions, } \\
\text { grams } \\
\end{array}$ \\
\hline & 2220 & 50 & 20.96 & 7.5 & 2220 & 1965 & 18602 \\
\hline
\end{tabular}

Table 6. Initial data for assessment the OJSC "Sovkhoz "Chervishevsky".

\begin{tabular}{|c|c|c|c|c|c|c|}
\hline \multirow[b]{2}{*}{ Process name } & \multirow{2}{*}{$\begin{array}{c}\text { Method of } \\
\text { implementation }\end{array}$} & \multicolumn{2}{|c|}{$\begin{array}{c}\text { Depletion of natural } \\
\text { resources }\end{array}$} & \multicolumn{2}{|c|}{ Waste generation } & \multirow{2}{*}{$\begin{array}{c}\text { Greenhouse } \\
\text { gas } \\
\text { emissions }\end{array}$} \\
\hline & & $\begin{array}{l}\text { Water } \\
\text { costs, } 1\end{array}$ & $\begin{array}{c}\text { The cost of } \\
\text { electricity, } \\
\text { kWh }\end{array}$ & $\begin{array}{c}\text { Losses } \\
\text { milk, } \\
\% \\
\end{array}$ & $\begin{array}{c}\text { Wastewater } \\
\text { formation, } \% \text { of } \\
\text { volume } \\
\end{array}$ & \\
\hline Milking & Milking parlor & 1224 & 25 & 1.5 & 100 & \\
\hline Milk cooling & Tank cooler & 720 & 25 & 2 & 100 & \\
\hline \multirow[t]{2}{*}{$\begin{array}{l}\text { Transportation } \\
\text { to the factory }\end{array}$} & & $\begin{array}{c}\text { The cost of } \\
\text { water per } 6 \\
\text { cubic } \\
\text { meters. m } \\
\text { liters }\end{array}$ & $\begin{array}{c}\text { Fuel } \\
\text { consumption, } \\
\text { l / 100km }\end{array}$ & $\begin{array}{l}\text { Losses } \\
\text { milk, } \\
\%\end{array}$ & $\begin{array}{l}\text { Soot emissions, gram } \\
\qquad / \mathrm{km}\end{array}$ & $\begin{array}{l}\text { CO2 } \\
\text { emissions, } \\
\text { grams }\end{array}$ \\
\hline & Diesel engine & 480 & 9.76 & 2.5 & 60 & 568 \\
\hline $\begin{array}{c}\text { Transportation } \\
\text { from } \\
\text { the factory }\end{array}$ & Diesel engine & 120 & 11.2 & 1.5 & 600 & 5680 \\
\hline
\end{tabular}




\begin{tabular}{|c|c|c|c|c|c|c|c|}
\hline \multirow[t]{2}{*}{ Total } & Water costs, 1 & $\begin{array}{c}\text { Electricity, } \\
\text { kWh }\end{array}$ & $\begin{array}{c}\text { Fuel } \\
\text { consumption, } \\
l\end{array}$ & $\begin{array}{l}\text { Loss of } \\
\text { milk,\% }\end{array}$ & $\begin{array}{c}\text { Wastewater, } \\
\text { l }\end{array}$ & $\begin{array}{l}\text { Soot, } \\
\text { gram }\end{array}$ & $\begin{array}{c}\mathrm{CO} 2 \\
\text { emissions, } \\
\text { grams }\end{array}$ \\
\hline & 2544 & 55 & 10.04 & 7.34 & 2544 & 660 & 6258 \\
\hline
\end{tabular}

Table 7. Initial data for assessment the PC "Milk".

\begin{tabular}{|c|c|c|c|c|c|c|c|}
\hline \multirow[b]{2}{*}{ Process name } & \multirow[b]{2}{*}{$\begin{array}{c}\text { Method of } \\
\text { implementati } \\
\text { on }\end{array}$} & \multicolumn{2}{|c|}{ Depletion of natural resources } & \multicolumn{3}{|c|}{ Waste generation } & \multirow[b]{2}{*}{$\begin{array}{l}\text { Greenhouse } \\
\text { gas emissions }\end{array}$} \\
\hline & & $\begin{array}{c}\text { Water costs, } \\
1\end{array}$ & $\begin{array}{c}\text { The cost of } \\
\text { electricity, kWh }\end{array}$ & $\begin{array}{l}\text { Losses } \\
\text { milk, \% }\end{array}$ & \multicolumn{2}{|c|}{$\begin{array}{c}\text { Wastewater } \\
\text { formation, \% of } \\
\text { volume }\end{array}$} & \\
\hline Milking & $\begin{array}{l}\text { Linear milk } \\
\quad \text { line }\end{array}$ & 768 & 20 & 1.5 & \multicolumn{2}{|c|}{100} & \\
\hline Milk cooling & Tank cooler & 480 & 35 & 2 & \multicolumn{2}{|c|}{100} & \\
\hline \multirow[t]{2}{*}{$\begin{array}{l}\text { Transportation to } \\
\text { the factory }\end{array}$} & & $\begin{array}{c}\text { The cost of } \\
\text { water per } 6 \\
\text { cubic meters. } \\
\text { m liters }\end{array}$ & $\begin{array}{c}\text { Fuel consumption, l / } \\
\text { 100km }\end{array}$ & $\begin{array}{l}\text { Losses } \\
\text { milk, \% }\end{array}$ & \multicolumn{2}{|c|}{$\begin{array}{l}\text { Soot emissions, } \\
\text { gram / km }\end{array}$} & $\begin{array}{c}\text { CO2 } \\
\text { emissions, } \\
\text { grams }\end{array}$ \\
\hline & Diesel engine & 480 & 1.28 & 2.5 & \multicolumn{2}{|c|}{120} & 1152 \\
\hline $\begin{array}{c}\text { Transportation } \\
\text { from the factory }\end{array}$ & Diesel engine & 120 & 12.8 & 1.5 & \multicolumn{2}{|c|}{1200} & 11520 \\
\hline \multirow[t]{2}{*}{ Total } & Water costs, 1 & $\begin{array}{l}\text { Electricity, } \\
\text { kWh }\end{array}$ & Fuel consumption, l & $\begin{array}{l}\text { Loss of } \\
\text { milk,\% }\end{array}$ & $\begin{array}{c}\text { Waste } \\
\text { water, } 1\end{array}$ & $\begin{array}{l}\text { Soot, } \\
\text { gram }\end{array}$ & $\begin{array}{c}\mathrm{CO} 2 \\
\text { emissions, } \\
\text { grams }\end{array}$ \\
\hline & 1848 & 55 & 14.16 & 7.8 & 1848 & 1320 & 12672 \\
\hline
\end{tabular}

The final data for the assessment are presented in table 8.

Table 8. Total score.

\begin{tabular}{|c|c|c|c|}
\hline & $\begin{array}{c}\text { CJSC } \\
\text { "Yasen- } \\
\text { Agro" }\end{array}$ & $\begin{array}{c}\text { OJSC "Sovkhoz } \\
\text { "Chervishevsky" }\end{array}$ & PC "Milk" \\
\hline Water costs, l & 2220 & 2544 & 1848 \\
\hline $\begin{array}{c}\text { The cost of water per } \\
\text { liter of product, l }\end{array}$ & 0.37 & 0.35 & 0.4 \\
\hline Electricity costs, kWh & 50 & 50 & 55 \\
\hline Fuel costs, l & 20.96 & 10.04 & 14.16 \\
\hline CO2 emissions, grams & 18602 & 6248 & 12672 \\
\hline Soot emissions, grams & 1965 & 660 & 1320 \\
\hline Waste, \% & 7.5 & 7.34 & 7.8 \\
\hline
\end{tabular}

Thus, the overall environmental impact was considered as the sum of the effects of each of the elements of the chain.

As follows from the analysis of the data presented in table. 8, OJSC "Sovkhoz "Chervishevsky" does the least damage to the environment in terms of water consumption and contribution to the production of greenhouse gases, which is explained by the use of a milking robot and the good location of the dairy farm and plant. Electricity costs are higher than competitors, which is also associated with the use of milking robots.

An analysis was also made of the environmental sustainability of supply chains in accordance with the indicators given in table 3 . The data obtained are presented in table 9 . 
Table 9. Environmental sustainability assessment results for supply chains.

\begin{tabular}{|c|c|c|c|}
\hline & $\begin{array}{c}\text { CJSC } \\
\text { "Yasen- } \\
\text { Agro" }\end{array}$ & $\begin{array}{c}\text { OJSC "Sovkhoz } \\
\text { "Chervishevsky" }\end{array}$ & $\begin{array}{c}\text { PC } \\
\text { "Milk" }\end{array}$ \\
\hline $\begin{array}{c}\text { Water costs for total } \\
\text { production }\end{array}$ & 2 & 2 & 2 \\
\hline Electricity costs & 1 & 1 & 2 \\
\hline Waste & 2 & 2 & 3 \\
\hline $\begin{array}{c}\text { Ecological standard of } \\
\text { transport }\end{array}$ & 2 & 1 & 2 \\
\hline Total transportation distance & 3 & 1 & 2 \\
\hline Final Average Rating & $\mathbf{2}$ & $\mathbf{1 . 4}$ & $\mathbf{2 . 2}$ \\
\hline
\end{tabular}

Thus, OJSC "Sovkhoz "Chervishevsky"has an indicator of environmental sustainability of supply chains equal to 1.4 , which corresponds to a high level compared to the average for the Russian Federation. At the same time, the enterprise would show the best possible result with the value of indicator 1. The supply chains of CJSC CJSC "Yasen-Agro" and PK "Milk" can be attributed to the average level of stability.

It is obvious that the differences between the levels of environmental sustainability of supply chains of different manufacturers do not indicate a different level of environmental management in these organizations, but differences in technological equipment and the geographical location of production relative to other parts of the supply chain. , The beginning of any practice to increase the level of environmental sustainability is not among the priority tasks of management and will not be included in the near future. Only relevant legislation can force owners to change priorities. In this case, the developed methodology can be used as a primary assessment of environmental sustainability, providing the opportunity to operate with measurable and understandable indicators for major environmental initiatives. Further steps to improve environmental sustainability will be aimed at transforming supply chains, changing their configuration in cooperation with suppliers and consumers.

\section{Conclusions}

Thus, a structural decomposition of the raw milk supply chains was carried out, seven main sub-processes were established: milking, transportation, filtration, milk cooling, transportation to the factory, processing and packaging, transportation to retail chains. The main environmental consequences of the logistic processes in the raw milk supply chain have been established: consumption of natural resources (water, fuel, electricity consumption), contribution to the generation of greenhouse gases, waste generation. A methodology has been developed for assessing the environmental sustainability of raw milk supply chains using a threelevel scale (high, medium and low sustainability). A checklist has been formed to assess the environmental sustainability of supply chains based on their various configurations. Based on empirical data, the environmental sustainability of supply chains of CJSC
Yasen AGRO, state farm Chervishevsky and Milk PK was assessed.

The authors see the direction of further research in creating a set of measures to reduce the loss of time and resources in the supply chain, the elimination of which can not only have a positive impact on the environment, but also affect the reduction of costs and increase the profitability of production. The link between environmental and economic indicators, the application of green supply chain management methods and individual performance indicators should be made apparent. Increasing the level of environmental responsibility of manufacturers, suppliers, logistics and consumers is an inevitable future in any country, since it determines the very possibility of the continued existence of mankind. The sooner enterprises accept the new realities of the functioning of the circular economy, the more likely they will remain competitive in the near future.

\section{References}

1. I. A. Anisimov, A. D. Burakova, and L. N. Burakova, in 2018 Int. Multi-Conference Ind. Eng. Mod. Technol. FarEastCon 2018 (2019)

2. A. D. Gorbunova, I. A. Anisimov, A. A. Fadyushin, M. Tishin, and D. A. Zakharov, in IOP Conf. Ser. Earth Environ. Sci. (2019)

3. P. Diehl and K. Conca, in Environ. Confl. (2018)

4 V. Prieto-Sandoval, C. Jaca, and M. Ormazabal, J. Clean. Prod. (2018)

5. G. A. Norris, Int. J. Life Cycle Assess. (2001)

6. Q. Zhu, J. Sarkis, and K. hung Lai, J. Clean. Prod. 15, 1041 (2007)

7. W. Chen, E. White, and N. M. Holden, J. Environ. Manage. (2016)

8. K. Refsgaard, N. Halberg, and E. S. Kristensen, Agric. Syst. 57, 599 (1998)

9. N. Goryaev, S. Tsiulin, I. Makarova, and K. Shubenkova, in Transp. Res. Procedia (2018), pp. 53-59

10. I. Makarova, K. Shubenkova, V. Mavrin, and N. Goryaev, in 2018 IEEE Int. Conf. Technol. Manag. Oper. Decis. ICTMOD 2018 (2019), 268-273 
11. L. N. Karlin, V. N. Malinin, and S. M. Gordeeva, Oceanology 55, 11 (2015)

12. M. Finkbeiner, A. Inaba, R. B. H. Tan, K. Christiansen, and H. J. Klüppel, Int. J. Life Cycle Assess. (2006)

13. C. Hohenthal, J. Leon, A. Dobon, M. Kujanpää, G. Meinl, J. Ringman, M. Hortal, and U. Forsström, J. Clean. Prod. (2019)

14. L. Cecchini, S. Venanzi, A. Pierri, and M. Chiorri, J. Clean. Prod. (2018)

15. B. Gil-Pulido, E. Tarpey, E. L. Almeida, W. Finnegan, X. Zhan, A. D. W. Dobson, and N. O’Leary, Biotechnol. Reports (2018)

16. T. Kocjančič, M. Debeljak, J. Žgajnar, and L. Juvančič, Agric. Syst. (2018)

17. I. Mitrofanova, T. Ivanova, R. Yalmaev, S. Zemlyanskaya, and I. Kudryuashova, in (2019)

18. M. Petrick and L. Götz, J. Agric. Econ. (2019)

19. S. Jafarzadeh-Ghoushchi, S. Dorost, and S. Hashempour, Int. J. Supply Chain Manag. (2018)

20. W. Ahmed, W. Ahmed, and A. Najmi, Manag. Environ. Qual. An Int. J. (2018)

21. R. S. Mor, A. Bhardwaj, and S. Singh, J. Oper. Supply Chain Manag. (2018) 